\title{
Communicating with the European Resistance: an assessment of the Special Operations Executive's wireless facilities in the UK during the Second World War
}

\author{
By DERWIN GREGORY
}

\begin{abstract}
SUMMARY: This article presents for the first time an examination of the Special Operations Executive's (SOE) UK-based communication facilities. Established in 1940, SOE was responsible for coordinating all acts of sabotage against the enemy overseas. This was only possible with the aid of a reliable communications link with the Resistance. By examining SOE's Home Stations, this article will demonstrate the value the organization placed in reliable wireless communications.
\end{abstract}

\section{INTRODUCTION}

In July 1940, the Special Operations Executive (SOE) was formed with a remit to

organize movements in enemy-occupied countries comparable to the Sinn Fein movement in Ireland, to the Chinese Guerrillas operating against Japan, to the Spanish Irregulars who played a notable part in Wellington's campaign or - one might as well admit it — to the organizations which the Nazis themselves have developed. ${ }^{1}$

Although SOEonlyexistedoperationally for 71 months, at its maximum size it employed 10,000 men and 3,200 women. ${ }^{2}$ Throughout the Second World War, the organization was involved in a wide variety of activities intended to support and stimulate resistance behind enemy lines. These included assassinations, sabotage, blackmail, organizing escape routes, training and arming partisans and gathering intelligence. In order to operate effectively, it was essential that the European Resistance had access to a modern communications network back to SOE in the UK. This link was essential for arranging the delivery of supplies to the organization's representatives operating within occupied Europe. Communications were also vital for reporting enemy activities, arranging for the extraction of personnel, coordinating operations and organizing missions. ${ }^{3}$ Without this direct link, SOE's agents and the wider resistance would have been isolated in hostile territory. ${ }^{4}$

In order to communicate with the European Resistance, it was essential that trained radio operators were embedded within their networks. These agents would have been provided with wireless sets by SOE. ${ }^{5}$ They would then communicate back to 'Home Stations' ${ }^{\prime}$ established by the organization in the UK. Although SOE did not gain control of their own wireless networks until 1942, by the end of the war they had invested heavily in developing modern communication facilities. Despite the essential nature of SOE's UK-based wireless facilities to the organization, no study exists which covers the physical infrastructure of their Home Stations. ${ }^{7}$ As the infrastructure of the Secret Services is less 'glamorous' than their operations, this area of research is, relatively speaking, not well understood. ${ }^{8}$ The aim of this article is therefore to address this gap in our knowledge.

Of the various aspects of SOE's UK-based support infrastructure, their communications facilities 
haveleft the greatest archaeological trace. Accordingly, this article will also briefly present the findings of a survey undertaken at SOE's Station 53B transmitter at Godington, Oxfordshire. ${ }^{9}$ Over the operational life of the organization, SOE was to become one of the most controversial branches of the British Secret Services. ${ }^{10}$ One of their greatest and most vocal critics was the Secret Intelligence Service (SIS), more commonly known as MI6. Until 1942, however, SIS was solely responsible for operating SOE's wireless communications with their representatives abroad. One of the goals of this article is to present an assessment of the value the two organizations placed in their wireless communications. In order to accomplish this, the article begins by presenting a history of SOE's wireless communications. This will then be followed by a discussion of the nature of the organization's Home Stations. As it was SIS's responsibility to communicate on behalf of SOE until 1942, the nature of their wireless facilities will also be examined. In order to assess the quality of the organization's wireless infrastructure, it is essential that a comparison is made with other contemporary communication facilities. Based on this discussion, the article will conclude with a holistic assessment of SOE's Home Stations during the Second World War.

\section{THE EARLY HISTORY OF SOE AND SIS WIRELESS COMMUNICATIONS}

Despite the high importance the organization was to attach to wireless communications, SOE was not initially in charge of its own networks. In September 1940, two months after the organization had been formed, an agreement was reached between SOE and SIS. ${ }^{11}$ This accord ensured that all traffic which originated from within SOE was handled by SIS. It was also agreed that the head of SIS (known as ' $\mathrm{C}$ ') had the right to reject any message which he deemed compromising to his organization's security. ${ }^{12}$ Understandably, this situation was far from ideal from SOE's standpoint. Despite being the elder service, SIS had no claim to being experts in the field of clandestine communications. At the time SOE and SIS signed their communications agreement, the latter had only recently started working with wireless technology.

\section{COMMUNICATING WITH THE RESISTANCE}

The origins of SIS's own network lie in the period immediately before the First World War. The Royal Navy first installed radio equipment into HMS Juro and HMS Europa in $1899,{ }^{13}$ but it was not until the spring of 1912 that Commander Mansfield Cummings, the first head of SIS, began contemplating using the technology. ${ }^{14}$ Cummings saw radios as a potential method of obtaining intelligence during periods of political tension. It was not for another 26 years, however, that SIS would finally establish a formal communications group. Command of the new Section VIII was offered to Captain Richard Gambier-Parry. ${ }^{15}$ As commercial technology had proved unsuitable for his requirements, one of the first and ultimately most difficult challenges Gambier-Parry faced was providing SIS's agents with wireless sets. ${ }^{16}$ At the time SOE and SIS reached their agreement on wireless communications the latter could, therefore, only call on two years' experience.

By having to rely on a third party to control their communications, SOE was at the mercy of a competing branch of the Secret Services. By March 1942, the organization had already begun noticing issues with their traffic. Though they were marked as being of the highest priority, SIS was not handling SOE's messages in an appropriate manner. Following an internal investigation, SOE determined that SIS took four days to deliver a telegram from their organization's Balkans or Middle East missions back to the UK. Of greater concern to the secretive SOE than the delay in receiving messages was the ability of $\mathrm{C}$ to impose an 'inquisitive censorship over the whole of our [SOE's] activities'. ${ }^{17}$ By not controlling their own wireless networks, SOE also faced the challenge that SIS maintained the ability to limit the number of agents the organization sent abroad. SIS was of the opinion that they held the authority to restrict SOE's agents to 'the capacity of the receiving scheme ... [and] by the fact that to increase the number to any extent will constitute a menace to security'. ${ }^{18}$ By April 1941, SOE had between 300 and 400 students undergoing instruction in their Special Training Schools (STSs). This number of agents, however, was too great for the 'necessary arrangements made by S.I.S. for the reception of their messages as and when they arrive in the countries where it is proposed that they should operate' ${ }^{19}$ In order to achieve the role allocated to SOE, it was essential that the organization could operate a greater number of agents within occupied Europe. The running of the organ-

ization's wireless communications by a competing branch of the Secret Services was far from ideal. It was, therefore, essential to SOE that a new agreement with SIS be reached.

Following prolonged discussions, SIS finally agreed in February 1942 to transfer operational control of SOE's wireless traffic to the organization. Despite this new agreement, there remained the caveat that SOE had to ensure that all necessary 'security requirements were met'. ${ }^{20} \mathrm{SOE}$ also agreed that $\mathrm{C}$ retained the right to reduce any of their channels if it was

found that interference or embarrassment to SIS communications resulted ... One more condition 
$\ldots$ is that it must be clearly understood that SOE will not, under any circumstances, undertake any communications for the representatives of any Allied Power without reference to me. ${ }^{21}$

On 27 March, SOE agreed to C's conditions. ${ }^{22}$ It was not until 1 June 1942, however, that the organization's wireless networks officially separated from SIS. ${ }^{23} \mathrm{SOE}$ was now in a position, free from SIS, to develop a highly professional, modern system of wireless communications with their agents operating within enemy-occupied Europe.

\section{THE ESTABLISHMENT OF SOE'S WIRELESS FACILITIES}

Once SOE gained control of their own wireless networks, the organization could begin establishing independent facilities. By the end of the war, the organization was communicating with occupied Europe from two Home Stations, whilst a third was operated on their behalf by the Office of Strategic Services (OSS) ${ }^{24}$ All these facilities were to be located between Bicester in Oxfordshire and Bletchley Park in Buckinghamshire (Fig. 1).

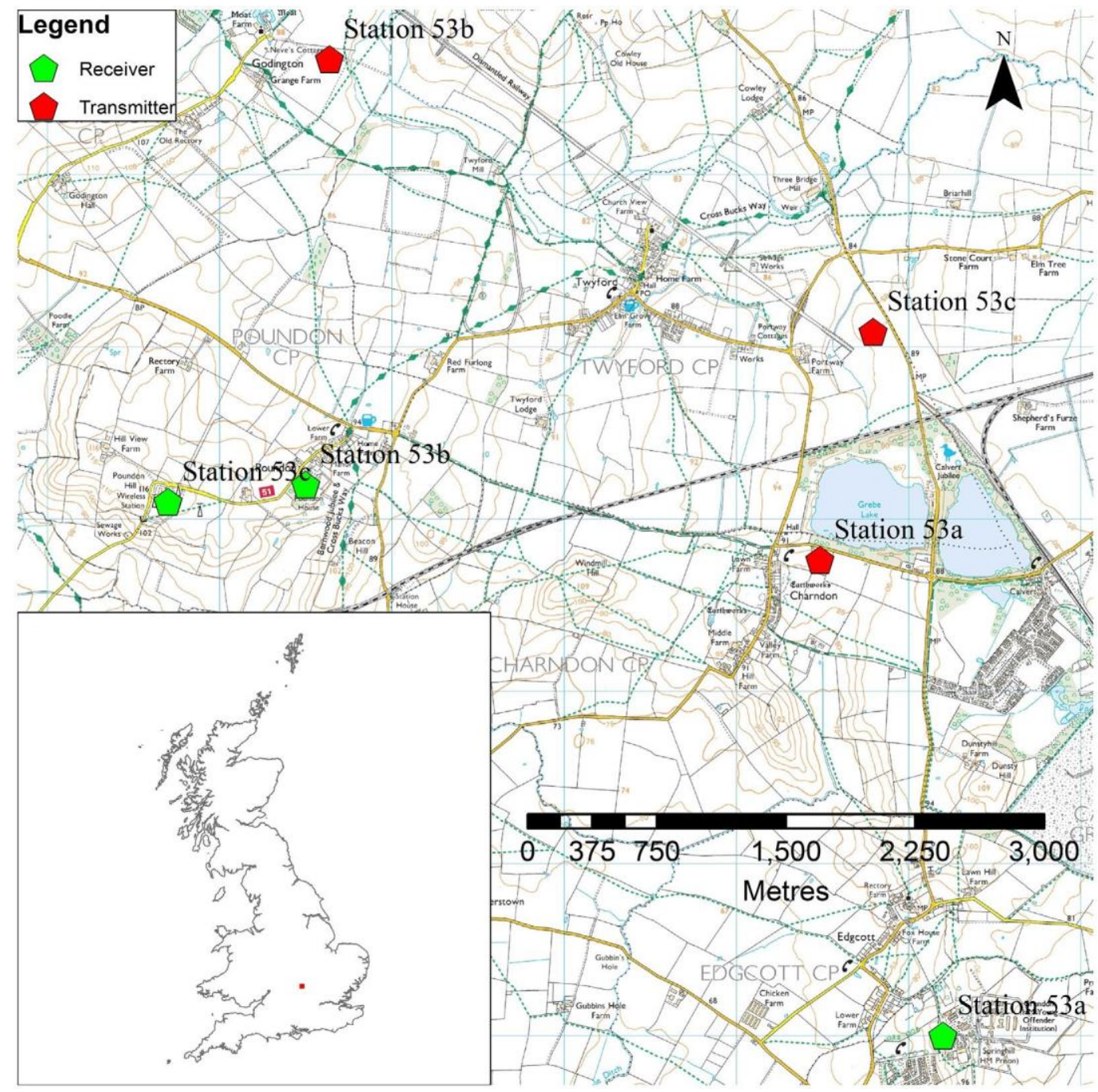

FIG. 1

The distribution of SOE's wireless Home Stations following the transfer of control of their communication networks from SIS to the organization (C Crown Copyright and Database Right 2015. Ordnance Survey Digimap Licence). 
Within four months of the new agreement between SOE and SIS, the former had already established their first Home Station. The receiving component of this facility was operated by the organization from Grendon Underwood, Buckinghamshire, and named Station 53A ${ }^{25}$ while the transmitter was at Charndon, Buckinghamshire. ${ }^{26}$ SOE's establishment of a communications facility at Grendon Underwood did not, however, go unchallenged by SIS. Despite protracted discussions which clearly identified this property as their preferred choice, in April 1942 Gambier-Parry began protesting that he had only just been informed of this decision. ${ }^{27} \mathrm{His}$ concerns centred on the fact that Grendon Underwood was only ten miles from one of his most important receiving stations and he felt that there was a strong possibility that interference would result as both organizations worked within the same frequency band. ${ }^{28}$ As a consequence of his concerns, Gambier-Parry informed SOE that he hoped they had not involved themselves 'in a lot of constructional work until the possibilities of interference have been thoroughly explored'. ${ }^{29}$ Despite his apprehensions, it was Gambier-Parry who had suggested that SOE establish their new receiving station at Grendon Underwood. ${ }^{30}$

By 13 April 1942, Gambier-Parry was of the opinion that it would be much better if we went into the matter now between our two selves and settled any possible causes of future disagreement before they arise, rather than wait until we have to take them formally to the W/T [Wireless Telegraphy] Board, should your detailed proposals be of a nature likely to cause embarrassment to existing services. ${ }^{31}$

Eventually, SIS conceded and SOE established their first receiver at what had been STS53. This formed the first building block in the organization's capabilities to independently handle their wireless communications.

\section{THE NATURE OF SOE'S COMMUNICATION FACILITIES}

The first attempt by SOE to establish wireless communications with occupied Europe was of a basic nature. Once SIS dropped their objections to the establishment of a receiver at Grendon Underwood, SOE constructed their first Signal Office in a downstairs room in the main house. As the transmitters and receivers had to be located in different areas, the organization established Grendon Underwood's partner facility nearby

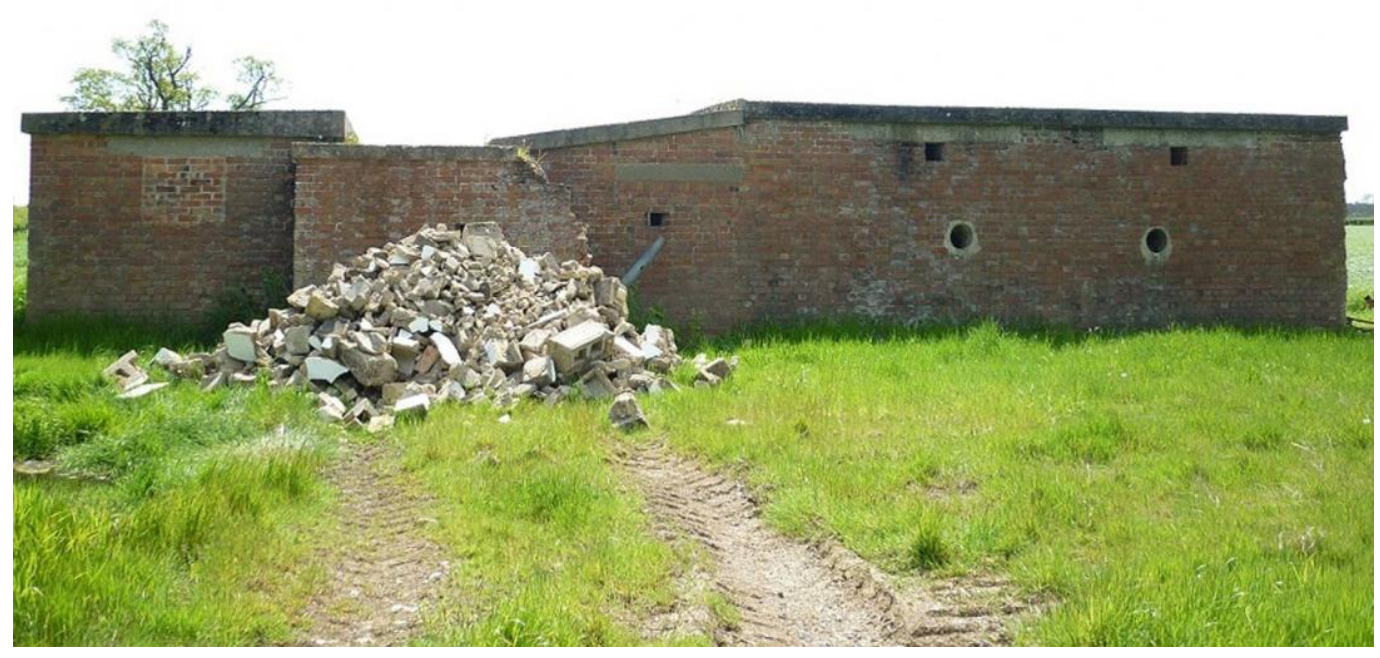

FIG. 2

SOE's first transmitter at Charndon in 2013. The structure to the left was the first transmitter building; the extension to the right was a later addition. Structural analysis indicates that there was at least three phases of construction (photo, D. 
at Charndon. Here, SOE constructed a building measuring $20 \mathrm{ft}(6.1 \mathrm{~m})$ by $12 \mathrm{ft}(3.66 \mathrm{~m})$ to house their transmitters (Fig. 2). This structure was connected to the receiver by a 20-pair cable. Inside, the organization installed equipment which enabled them to operate the 18 250w transmitters by remote control. The limited capacity of this complex was, however, rapidly outstripped by SOE's increasing traffic volume. It was, therefore, inevitable that the organization experienced a considerable loss of efficiency and flexibility in their wireless communications. ${ }^{32}$

In an effort to alleviate the overcrowding SOE experienced at Grendon Underwood, a decision was taken to construct a new Signal Office within the estate. This structure rapidly proved a considerable improvement over the ad hoc facilities in the main house. Inside the Signal Office, SOE installed eighteen operating positions. ${ }^{33}$ The organization also ensured that the new superintendent's desk had the capability of connecting any position to any transmitter. This desk was also provided with the ability to monitor communications over all the receivers. In parallel to this building programme, SOE also expanded their transmitter complex at Charndon by adding an extension measuring $35 \mathrm{ft}$ (10.67m) by $18 \mathrm{ft}(5.49 \mathrm{~m})$ to the existing building. SOE installed a further six $250 \mathrm{w}$ transmitters in the latter. ${ }^{34}$

Despite this expansion in capacity, the building programmes only provided SOE with a temporary respite. It was not long before the organization's demands once more outstripped their wireless capabilities. Eventually, SOE decided the solution to their problems was to build a dedicated facility. Within six months of gaining operational control of their wireless networks from SIS, SOE began constructing their first purpose-built Home Station. ${ }^{35}$ The location chosen for the new receiver was Poundon, Oxfordshire, and the transmitter was erected at Godington, Oxfordshire. ${ }^{36}$

In order to meet the increasing demands on their wireless facilities, SOE's new receiving station at Poundon was designed to be sustainably larger than the organization's facility at Grendon Underwood. Within the organization, this Home Station was to become known as Station 53B. The facility's receivers were installed in a purpose-built structure measuring $40 \mathrm{ft}$ (12.19m) by $40 \mathrm{ft}(12.19 \mathrm{~m})$ by $12 \mathrm{ft}(3.66 \mathrm{~m})$ (Fig. 3$)$. Into this building, SOE installed 40 operating positions, of which over half were adapted for automatic sending. In an effort to economize on antennae, the organization also installed new Wide Band Receiving Amplifiers within their structure at Poundon. This gave SOE the ability to operate as many as 50 receivers simultaneously from each amplifier. ${ }^{37}$

The transmitter complex for SOE's new Home Station was erected nearby at Godington (Fig. 4). ${ }^{38}$ The organization's internalized building section incorporated contemporary design standards for wireless stations during the latter's facility's construction. ${ }^{39}$
To limit the impact of the generators on the delicate wireless equipment, a separate structure was erected besides the Transmitter Building. The structure which held the transmitters measured $100 \mathrm{ft}(30.48 \mathrm{~m})$ by $24 \mathrm{ft}(7.32 \mathrm{~m})$ and incorporated features which allowed open wire feeder routes (Fig. 5). Constructed from red bricks laid in English bond, this building differs from the Sussex bond brickwork of the Generator Building. Internally, the Transmitter Building is arranged into four rooms in which various fixtures and fittings survive. The floors in these rooms is poured concrete of a finer grade than that of the Generator Building. Originally, the entrances were located on the eastern elevation and on the western edge of the northern elevation. At a later date, two further later entrances were formed by demolishing sections of the northern elevation onto which an lean-to was erected following decommissioning. The posts which formed this extension were originally telegraph poles which probably formed the antennae of Station 53B. Along both the northern and southern elevations are fifteen narrow windows located just beneath the roof line.

Within the Transmitter Building (Fig. 8), the equipment was placed within Room 4 and Room 5. ${ }^{40}$ This space was designed so that the transmitters could be arranged along both walls which ran the length of the building. ${ }^{41}$ Originally, this room was $3.6 \mathrm{~m}$ tall, $7.32 \mathrm{~m}$ wide and $30.2 \mathrm{~m}$ long. This created a light and airy space in which the transmitters could be operated. By constructing this large room, SOE also provided their engineers with sufficient space to inspect, repair and replace their equipment easily and efficiently. Into this room, SOE housed 34 250w transmitters together with their remote-control apparatus. In order to connect up all this equipment, the organization had to acquire over $6,000 \mathrm{ft}(1,828.8 \mathrm{~m})$ of lead-covered wire. ${ }^{42}$ Direct access to the outside was via a doorway built into the eastern elevation of this room. Through this, equipment could be easily moved in and out of the structure.

To the west of the transmitter room, a doorway led into the complex's office. Along the southern elevation of this space, a slit cut into the wall allowed staff to observe the antennae which were erected in the fields around the structure. The main entrance to the Transmitter Building was through a cloakroom leading off the office.

In comparison, the Generator Building sat atop

two courses of engineering bricks (Fig. 6), and is arranged into seven distinct areas (Fig. 7). Entrance to the main structure is via a door located on the eastern edge of the northern elevation. Two smaller rooms, which are accessed separately, are located in the western end of the structure. The lack of external windows in these spaces, combined with their confined area, indicates that these were probably intended for storage.

Entrance to the main structure is via an open doorway on the eastern end of the northern elevation. 


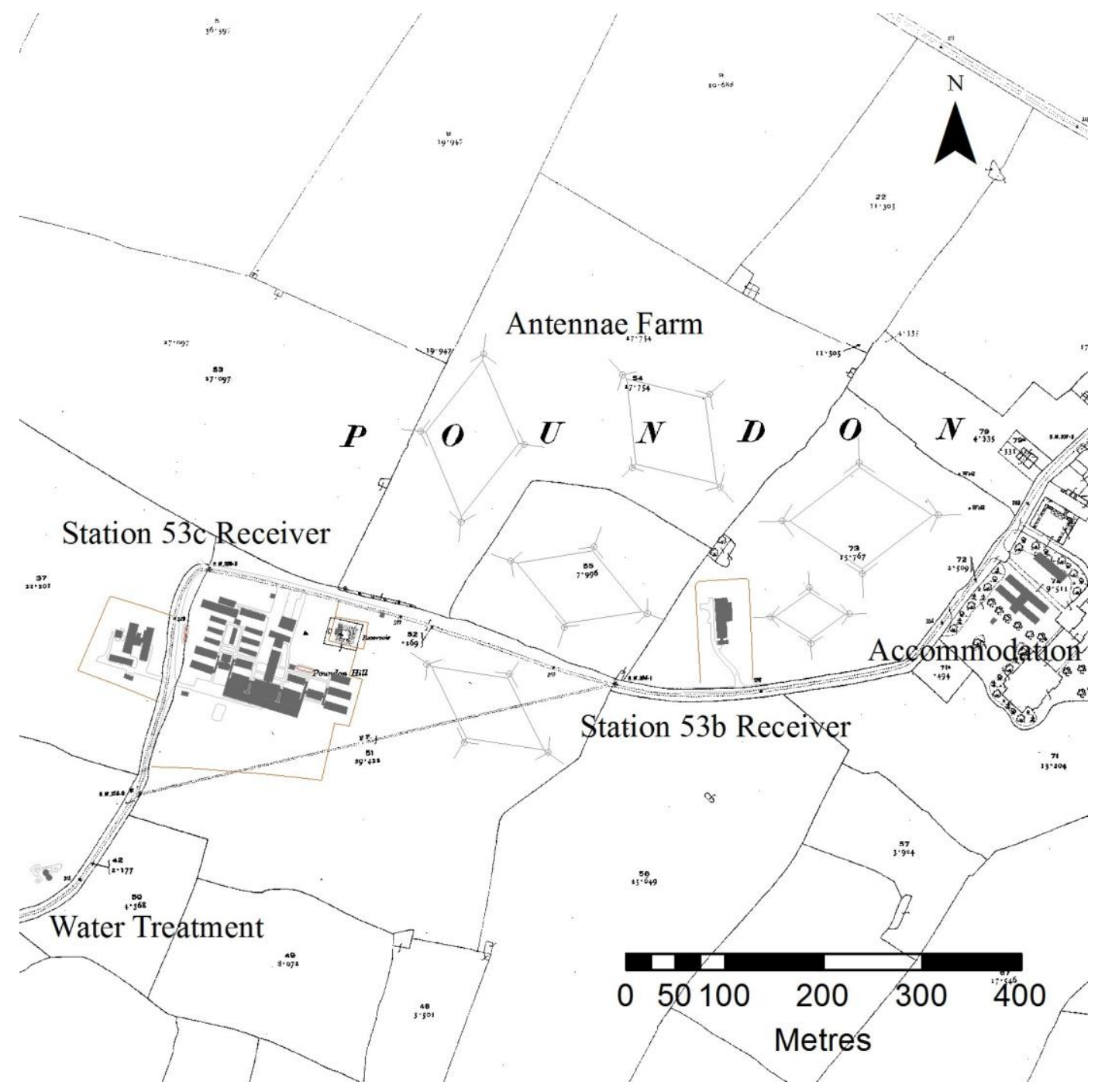

FIG. 3

The receiver of SOE's first purpose-built Home Station, Station 53b, was located in Poundon, Oxfordshire. Nearby, Station $53 \mathrm{c}$ was constructed by SOE on behalf of the OSS (ㄷ Crown Copyright and Landmark Information Group Limited 2015. rights reserved).

On entering the structure, the entrance 'hallway' was originally split into two distinct areas by a waist-high swing door. ${ }^{43}$ This arrangement suggests that these spaces were used as a cloakroom or changing facility for staff entering the generator room. ${ }^{44}$ Beyond this 'hallway' was located the room which housed the generator. Within the poured concrete floor of Room 5 is a rectangular mark, $1.07 \mathrm{~m}$ wide and $3.29 \mathrm{~m}$ long. Set within this are two rows of five metal bolts which project $0.02 \mathrm{~m}$ from the concrete floor. Onto these,
SOE would have bolted the generator. This ensured vibrations caused by the generator could not damage the equipment.

Passing through the generator room, there is an enclosed space which has no external windows or doors. There are also no obvious signs that there were originally internal fixtures or fittings. The room was, therefore, probably used to store items. Surviving on the western elevation of this room are a series of pencil inscriptions. Although degraded, it 


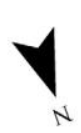

Transmitter Building

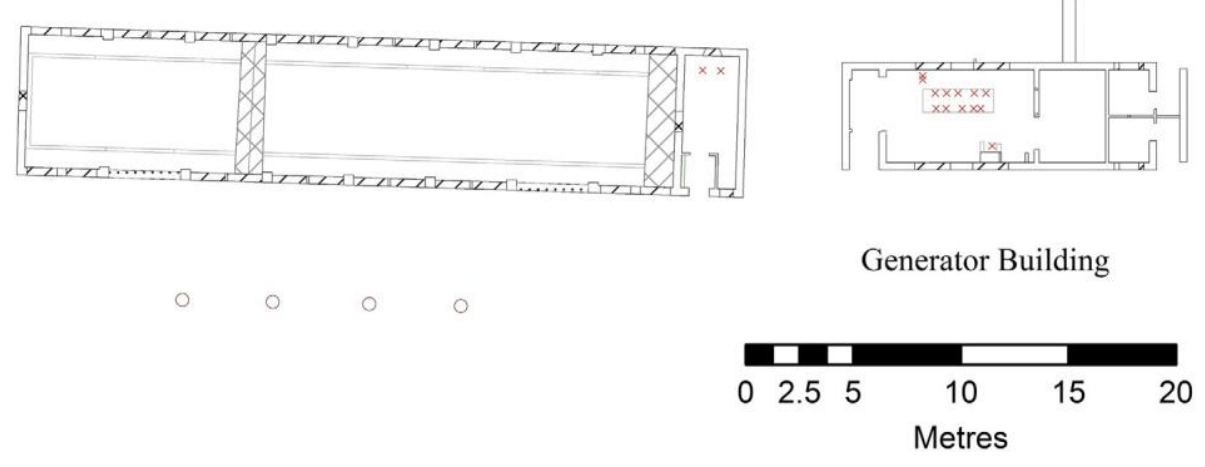

FIG. 4

Architectural survey of Station 53B transmitter, Godington (drawing, D. Gregory).

is possible to identify 'For men may come and men may go' and 'Roll of Honour' ${ }^{45}$ Beneath this is a collection of pencil graffiti which includes 'BENJAMIN DECEASED JAN - 45', 'J. DREWERY JUNE 1945' and 'ASSISTANT INSPECTOR BILL HORSEY RAF JULY $1945^{\prime} .^{46}$ These dates are consistent with the occupation of the building by SOE. Whom they refer to is currently less easy to ascertain. As Godington was operated by remote control by staff based at Poundon, it was only necessary for the engineers who looked after the equipment to be stationed at the transmitter. This facility would therefore not be in direct contact with agents in the field. Even if the staff were aware of agents operating within occupied Europe, knowledge of their real names would constitute a security lapse. These names therefore potentially record people known to SOE's staff based at Godington who were killed during the war. As the graffiti is located within Room 6 of the Generator Building, this suggests that there was a high footfall of staff using this space.

Further storage space within the Generator Building was provided by the construction of Room 7. this extension was probably added to the structure at the time the Transmitter Building was erected. As there was no overhead cover, the items held here were presumably neither perishable nor delicate. During the construction of the Generator Building, SOE's builders ensured that there was sufficient space for storing essential equipment and supplies. This structure was also designed specially to limit the impact of the vibrations produced by the generator. Combined, the two buildings which formed SOE's Station 53B were well designed, modern and ideally suited to their specific requirements. In order to damp-proof the building, a layer of slate was set within the brickwork.

Disparities in construction between the Generator and Transmitter Buildings suggests that they were erected at different times. This is further illustrated by the fact that the construction style of the Transmitter Building is similar to Room 7 of the Generator Building. Room 7 is not keyed into the main structure which housed the generator, suggesting that there were two phases of construction at SOE's transmitter complex at Godington: initially the Generator Building was erected, followed by the Room 7 extension and the Transmitter Building. ${ }^{47}$

Following the construction of Station 53B, SOE once more discovered that their flow of wireless traffic still outstripped their capacity to handle messages. As a consequence, the organization decided to install Wide Band Receiving Amplifiers at Stations 53A's transmitter at Charndon. ${ }^{48}$ Instead of upgrading their existing facility, the decision was taken to construct a new building based on the design of Godington. ${ }^{49}$ This structure allowed SOE to centralize their equipment into a single building, whilst also providing sufficient space for the number of transmitters to be increased. By constructing another facility, SOE could also install a new 'trouble-free' remote control system. In order to 


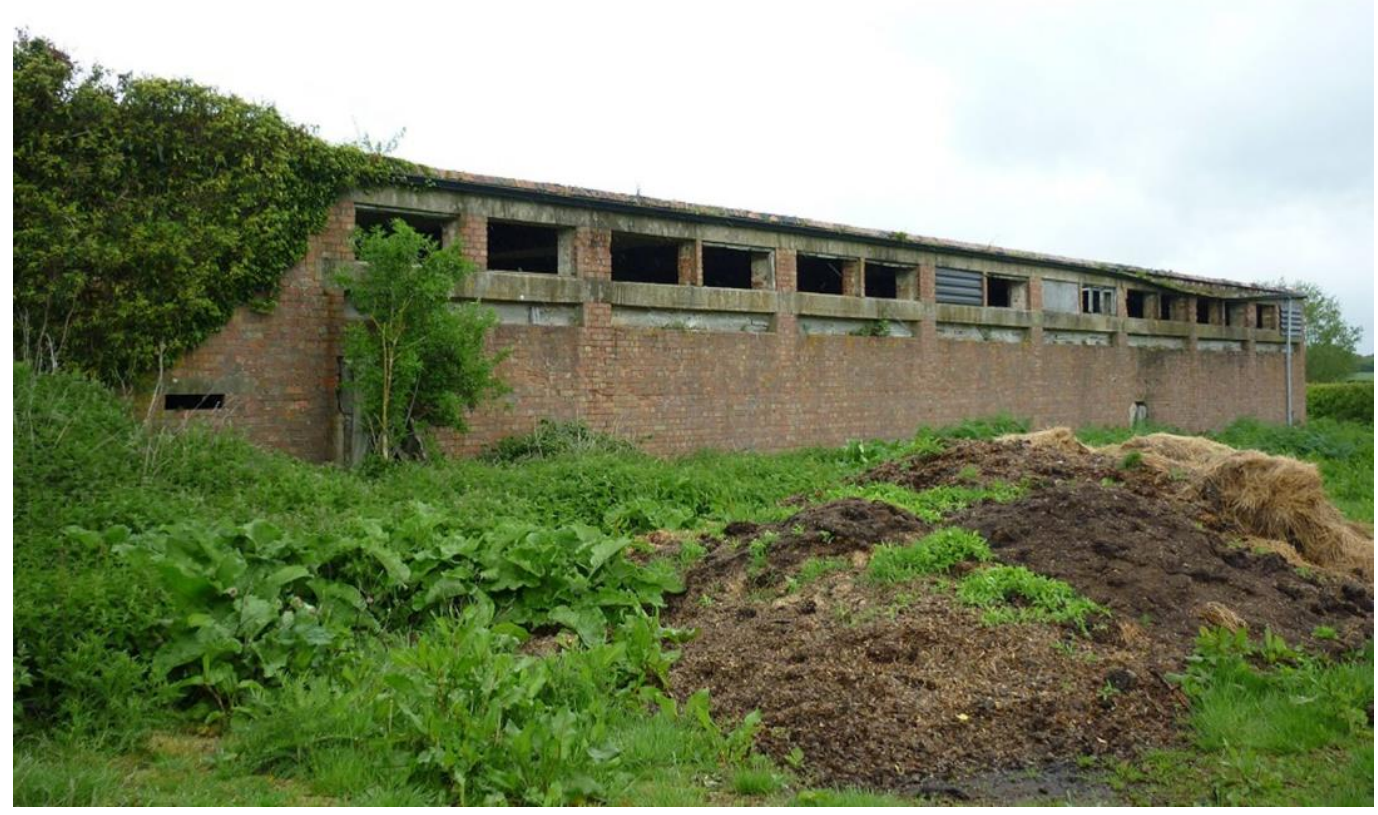

FIG. 5

The southern elevation of the Transmitter Building at SOE's Station 53B in 2013 (photo, D. Gregory).

operate this, the organization required over $3,000 \mathrm{~m}$ of twin lead-covered wire. ${ }^{50}$ Messages were then transmitted over the 35 dipoles and two rhombic antennae which were constructed nearby. ${ }^{51}$ To connect all these antennae, the feeder route required an additional $100,000 \mathrm{ft}(30,480 \mathrm{~m})$ of copper wiring. ${ }^{52}$

In constructing their Home Stations, SOE invested significant resources in an effort to establish reliable and efficient communications. This clearly illustrates the value the organization placed on being able to contact their representatives abroad. Despite this, on the formation of SOE the organization's wireless networks were not under their direct control. Following an agreement between SIS and SOE to transfer operational control of the latter's communications, SOE rapidly began developing ad hoc facilities. Within six months, however, operational requirements necessitated that the organization had to construct a purpose-built Home Station. This initiated a programme of work upgrading their existing facilities, combined with constructing new Home Stations. In order to comprehensively assess the nature of SOE's wireless stations, it is essential that a comparison is made with contemporary facilities. By undertaking this assessment, SOE's appreciation of the value of wireless communications can be demonstrated.

\section{COMPARISON BETWEEN SOE'S HOME STATIONS AND OTHER CONTEMPORARY WIRELESS FACILITIES}

The construction of SOE's Home Stations did not occur in isolation: there were other contemporary organizations which were also involved in wireless telegraphy. It is, therefore, of value to compare SOE's Home Stations with those of their peers. As will be demonstrated, despite internalizing their building capabilities in $1942,{ }^{53}$ the architectural and technological nature of SOE's Home Stations were in keeping with contemporary design standards.

At the time SOE was formed, the greatest expertise in wireless broadcasting within the UK lay with the 


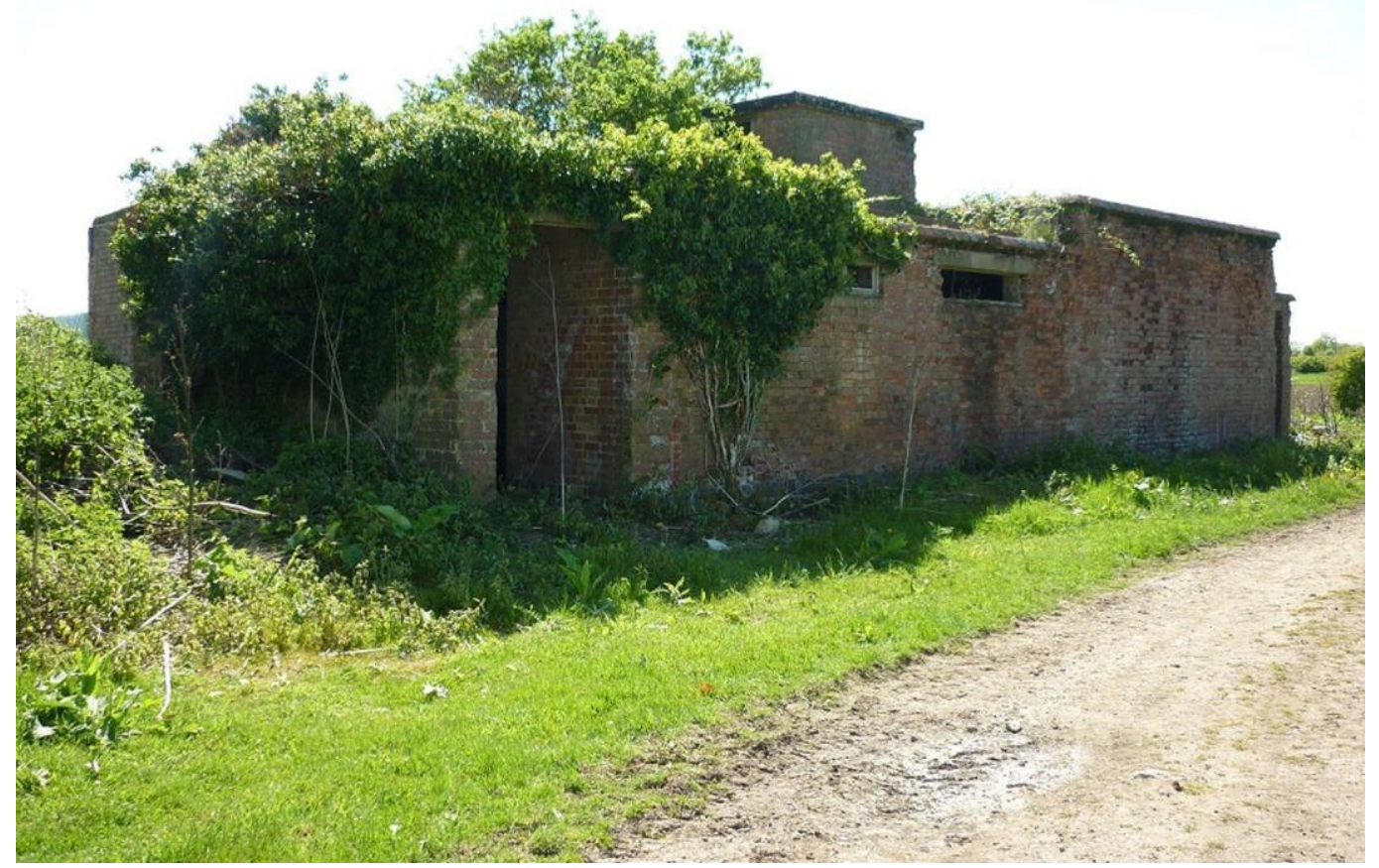

FIG. 6

The northern elevation of the Generator Building at SOE's Station 53B transmitter, Godington, in 2013 (photo, D. Gregory).

British Broadcasting Corporation (BBC). Twenty years prior to the outbreak of the Second World War, the BBC had identified that the majority of 'shut downs' in their broadcasting service had been caused by failings in the National Grid. In an effort to overcome this issue, the corporation established a regional network of twin wireless transmitting stations. Each of these facilities was provided with a self-contained generating plant. In constructing these units, the BBC could offer a more reliable service combined with the ability to fluctuate voltage. ${ }^{54}$

Once the BBC had taken the decision to provide independent power to broadcasting facilities, the corporation had to address issues relating to the impact of the generators on the quality of transmissions. If careful consideration was not taken in positioning the equipment, noise and vibrations from the generators could have a serious negative impact on the delicate wireless sets. It was also essential for the comfort of the technicians operating the equipment that silence prevailed in the room holding the transmitters. This had the added benefit of making it easier for staff to locate faults caused by arcing and sparking. ${ }^{55}$

In an effort to minimize the impact of the generator on the delicate wireless equipment, a variety of techniques could be employed. At the General Post Office (GPO) short-wave receiving station constructed in the 1930s on the Hoo Peninsular, Kent, the generator was located in a room which, although connected to the main structure, was isolated from the rest of the building. ${ }^{56}$ Not only did this limit the impact of the vibrations, but it also ensured that dust and noise produced by the generator did not affect staff and equipment in the main building. It was not, however, always possible to physically segregate the generator from the rest of the building. In these situations, it was essential that the engineers could find alternative methods of limiting the negative impact of the generator. Staff at the WRC broadcasting station, which occupied a preexisting office building on 14th Street and Park Road, Washington D.C., USA, mounted their generator on a steel bed atop a $0.08 \mathrm{~m}$ cork mat. ${ }^{57}$ This was designed 


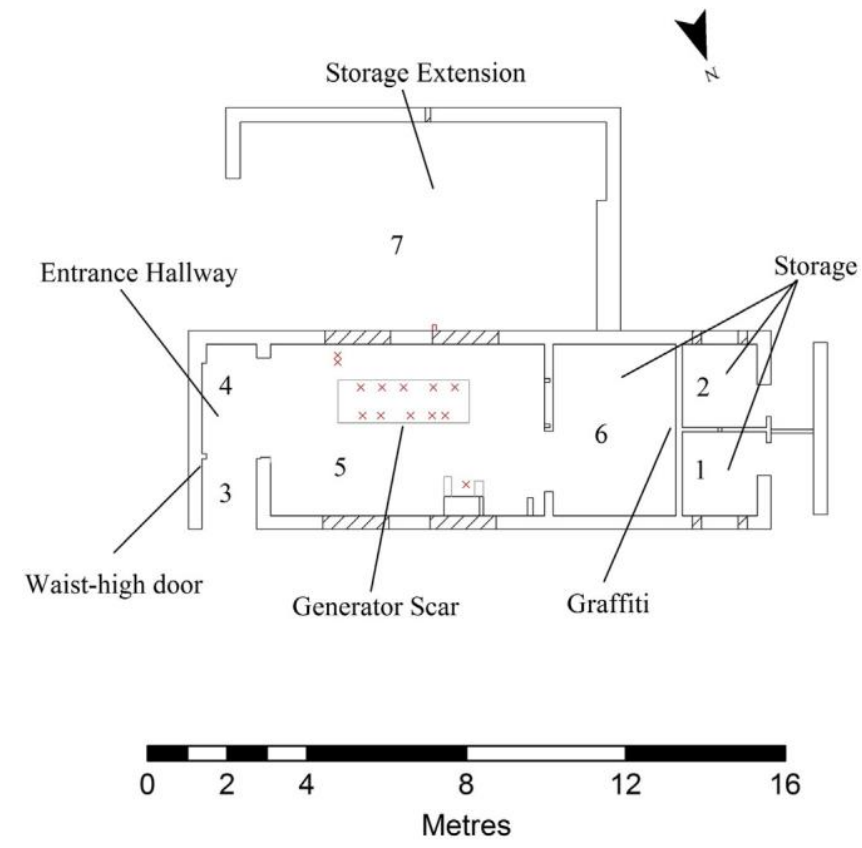

FIG. 7

Floor plan of the Generator Building (drawing, D. Gregory).

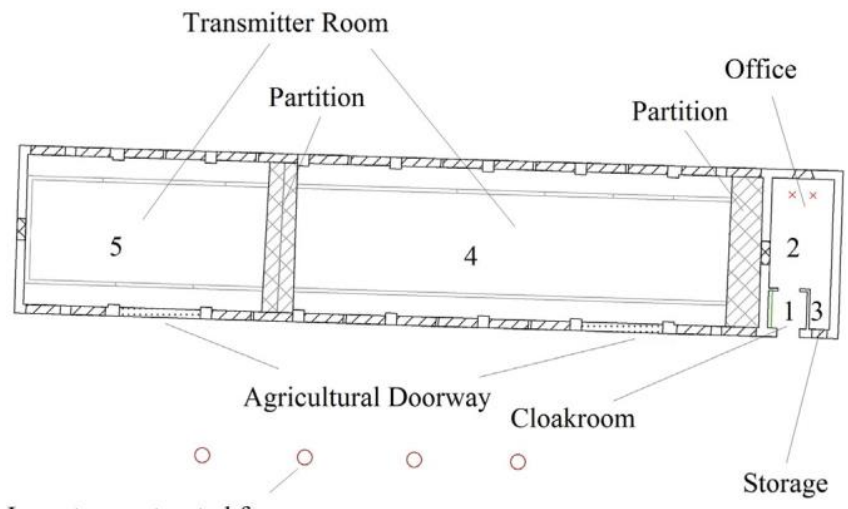

Lean-to constructed from telegraph poles

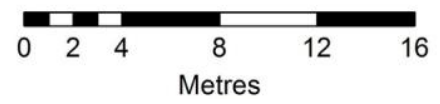

FIG. 8

Floor plan of the Transmitter Building (drawing, D. Gregory). 
to act as a cushion, absorbing vibrations produced by the generator.

It is clear that, during the construction of SOE's transmitter complex at Godington, the organization's builders adhered to contemporary design standards for wireless facilities. ${ }^{58}$ Not only was the generator installed in a building separated from the wireless equipment, it was also bolted to a concrete bed inset within the floor. By isolating the generator and bolting it to the ground, SOE shielded their delicate transmitting equipment from vibrations and dust. The isolation of the generator was not the only contemporary design standard adhered to by SOE during the construction of their transmitter building at Godington. At the 50kw frequency-modulation transmitter in the Helderberg Mountains, New York, USA, the station was designed to allow staff the maximum accessibility to components for inspection and maintenance. ${ }^{59} \mathrm{In}$ contrast, at facilities operated by the BBC, this was accomplished by placing the wireless equipment along walls either side of the structure. By keeping the rest of the space free from clutter, staff could easily maintain the equipment. ${ }^{60}$ At Godington, the same design standards were incorporated into the room which held the transmitters; the equipment was arranged along the two external walls within a large, airy room. Despite SOE internalizing the construction process by forming an internal building section during $1942,{ }^{61}$ the organization demonstrated a high level of knowledge and competence of contemporary design standards.

As has been discussed, until June 1942 it had been SIS's responsibility to communicate with SOE's representatives abroad. Comparing the two organization's facilities is therefore instructive. From the outbreak of the Second World War, SIS's communications were the responsibility of Section VII. ${ }^{62}$ Initially, this section operated from rooms within Bletchley Park, Buckinghamshire. ${ }^{63}$ The limited space available and the ad hoc arrangement meant this facility rapidly proved insufficient for SIS's needs. Before the close of 1939, SIS's Section VIII was already in the process of relocating to Whaddon Hall, Buckinghamshire. ${ }^{64}$

Whaddon Hall was to become SIS's new 'Main Line' station. At this facility, Section VIII handled the organization's traffic which originated from within embassies and overseas missions, as well as covert stations on the Continent, and they occasionally communicated directly with agents. As the war progressed, further wireless facilities were established by SIS at Dower House, Buckinghamshire, Windy Ridge, Buckinghamshire, Tattenhoe Barn, Buckinghamshire and Creslow Manor, Buckinghamshire. ${ }^{65}$ It took SIS until early 1940, however, before they began constructing their first purpose-built wireless facility for handling agents' traffic alone. By the end of the year, construction had finished at SIS's new receiving station at Nash, Buckinghamshire. The transmitter for this complex was located at Manor Farm, Calverton, Buckinghamshire. Later in the war, a further receiving station was constructed by SIS at Upper Weald, Buckinghamshire. This new facility also worked with the transmitters located at Manor Farm. ${ }^{66}$

At SIS's receiving facility located at Nash, the organization constructed a shed to house their equipment, and a brick-built generator building with an attached battery store. Nash's sister station located at Upper Weald was slightly larger; here, two sheds were provided alongside the brick-built generator and battery store. ${ }^{67}$ These structures were cramped and basic in comparison to SOE's spacious, professional and well thought-out wireless facilities. ${ }^{68}$ In order to operate their receiving facility at Nash, SIS employed nine men on a three-watch system. One of these operators, Jack White, recalled that the organization installed eight receivers at Nash; seven HROs, manufactured by the National Radio Company, and his personal battery-operated AR88. Whilst at SIS's complex at Manor Farm, the transmitters comprised various American 750w and British 100w and 30w sets. Due to the quantity of American equipment operated from this facility, SIS accommodated four engineers from the US Civilian Technical Corps at Manor Farm to maintain the transmitters. ${ }^{69}$ Although the nature of the antennae at SIS's facilities is unknown, it is known that, at Upper Weald, messages from the field were received over semi-vertical wires suspended from relatively low cantilever wires. It was not until 1944 that this system was improved, when SIS arranged for a crew of aerial erectors to visit the facility. ${ }^{70}$ Overall, the facilities operated by SIS were under-resourced and undervalued. Even amongst SIS's Section VIII radio operators there existed a feeling that the organization viewed communicating with their agents as a lower priority than intercepting enemy transmissions. ${ }^{71} \mathrm{In}$ contrast to the ad hoc facilities operated by SIS, SOE rapidly developed a network of modern wireless stations. This reflected the value the organization placed on communicating with their representatives abroad.

\section{DISCUSSION}

With the development of wireless technology at the end of the 19th century, a new dimension was brought to the battlefield. By having access to instantaneous, long-distance communications, the military could act on intelligence which had been relayed in real-time. Through assessing SOE's Home Stations, it is clear that the organization appreciated the value of wireless communications to clandestine operations. By ensuring they had a direct link with their representatives abroad, SOE had the capabilities to organize supplies, coordinate operations and collect intelligence. The link 
back to the Allies was also highly regarded within the European Resistance and radio operators were thus highly prized. ${ }^{72}$

Despite the importance of communications to SOE's operational efficiency, SIS retained control over their wireless networks on the formation of the organization in $1940 .{ }^{73}$ The head of SIS, C, was also

absolutely opposed to any other Secret W/T Service being set up in the U.K. I [C] fought long enough to try and maintain one Secret Service, and this would be another step in the wrong direction, apart from the unlikelihood of S.O.2 being able to set up anything for many months which would give efficient results. ${ }^{74}$

This adverse situation allowed SIS the ability to read and censor all traffic which originated from within SOE. There existed the general consensus within SOE that ' $C$. telegrams take complete preference over [ours]'. ${ }^{75}$ As SOE's messages were treated as a lower priority than those of SIS, there was an inevitable delay in the organization's communications. This delay was anticipated to get worse as SOE grew. ${ }^{76}$

As it became apparent that SIS's control of their wireless communications was having a negative impact on the organization, SOE started arguing the case for running their own networks. It was not until 27 March 1942 that the two organizations finally reached an agreement. ${ }^{77}$ By 22 May, SOE were in a position to begin transmitting. ${ }^{78}$ Official separation, however, did not occur until 1 June $1942 .{ }^{79}$ As has been discussed, it took SOE a number of months to construct their two independent Home Stations. Transferring operational control of the organization's wireless networks was, therefore, not an instantaneous event.

Despite their relatively late arrival in the field of wireless communications, the theoretical quality of SOE's Home Stations quickly outstripped those of SIS. In comparison to SOE's wireless facilities, those operated by SIS were basic, cramped and did not contain standardized equipment. The lack of resources invested by SIS into wireless networks suggests that the organization placed little emphasis on the need to communicate with their representatives. For two branches of the British Secret Services who both needed to communicate abroad, ${ }^{80}$ there existed a clear disparity between the wireless facilities of SOE and SIS. The quality of SOE's communications was also recognized by their contemporaries. In preparation for Operation Overlord (the Battle of Normandy), the organization was allocated 200 frequencies for clandestine activities and a further 66 for joint military operations. ${ }^{81}$ Together, these represented $13 \%$ of all frequencies allotted for the invasion of Europe. Although this was less than those operated by the army and air force, SOE was provided more frequencies than the Royal Navy for Operation Overlord. ${ }^{82}$
By dedicating a large proportion of the wireless networks for the invasion of Europe to SOE, the armed services were demonstrating their faith in the organization's communications capabilities. In addition, SOE were also tasked by the War Office with supplying all Special Forces involved with the one-time pads they had developed. ${ }^{83}$ During the Second World War, SOE placed value on the development of their Home Stations. This was rewarded by their contemporaries within the armed services having faith in their ability to communicate with the field.

\section{CONCLUSION}

This article has, for the first time, presented an initial assessment of the wireless facilities operated by SOE from the UK throughout the Second World War. Until 1942, it had been the responsibility of SIS to communicate on behalf of this 'competing' branch of the British Secret Services. Reluctantly handing over control in June, it took SOE a number of months to develop the capacity to take complete control of their networks. Until that point, a portion of their traffic was presumably still handled by SIS's basic and cramped facilities.

By the end of the war, SOE was operating a number of modern wireless facilities specifically constructed to communicate with the European Resistance. The resources invested by the organization in developing their Home Stations clearly illustrates that SOE valued reliable and efficient wireless networks. This allowed the organization to communicate directly with their agents and members of the resistance operating within occupied Europe throughout the Second World War.

In contrast to SOE's modern and resource-heavy Home Stations, SIS's wireless facilities were underresourced and of a basic nature. Until June 1942, it was the responsibility of these stations to communicate to occupied Europe on behalf of SOE. SIS was also responsible for providing SOE's agents with the insecure 'poem codes' ${ }^{84}$ This article has demonstrated that the transfer of control of SOE's wireless networks was not, however, prompt following the agreement reached between the organization and SIS in June 1942. Based on this analysis, the role played by SOE in the Operation Nordpol disaster, therefore, could potentially be reassessed, a research opportunity for the future. ${ }^{85}$

\section{ACKNOWLEDGEMENTS}

This article originated from a $\mathrm{PhD}$ written by the author and funded by the Centre for East Anglian Studies. The 
author would like to thank Professor Robert Liddiard, Dr James Dixon, Wayne Cocroft and Penny and Nigel Oakey: This paper is published with financial assistance from the Centre of East Anglian Studies.

\section{NOTES}

${ }^{1}$ Foot 1993, 18.

${ }^{2}$ Foot 1993, 14.

${ }^{3}$ Bailey 2008a, 186; 2008b, 57; Haestrup 1976, 189;

Kedwood 1994, 182.

${ }^{4}$ Amongst the resistance networks, a high value was placed on their ability to communicate with the UK (Lorain 1983, 34).

${ }^{5}$ These wireless sets were generally designed by SOE's Research and Development Section. Equipment was also developed on behalf of SOE by the Polish Military Wireless Research Unit (PMWR).

${ }^{6}$ 'Home Stations' was the name used by SOE to refer to a transmitter and receiving complex working together to communicate with their representatives abroad.

${ }^{7}$ See Gregory 2015.

${ }^{8}$ See Gregory 2013 . The vast majority of studies into SOE have focused on the 'glamorous' exploits of the organization's agents abroad. Research into SOE's Country Sections is so firmly entrenched into the mentality of SOE scholars that there is a danger that topics which do not fit into operational boundaries will be overlooked (Murphy 2005, 205).

${ }^{9}$ Although other structures which formed SOE's Home Stations also survive, permission could only be granted to access and survey the facility at Godington.

${ }^{10}$ West 1992, 1.

${ }^{11} \mathrm{SOE}$ was formed by the combination of SIS's Section D, the War Office's MI(R) and Department EH.

${ }^{12}$ Stafford 1980, 38.

${ }^{13}$ Cocroft 2013, 66.

${ }^{14}$ Jeffrey 2010, 30.

${ }^{15}$ Richard Gambier-Parry was made a Brigadier in 1942.

${ }^{16}$ Jeffrey $2010,10,262,318$.

${ }^{17}$ TNA: HS 8/358 SO2 Communications through C, 9 March 1941), 2.

${ }^{18}$ TNA: HS 8/358 To CD from E, 16 March 1941, 1.

${ }^{19}$ TNA: HS 8/358 S.O.2 Communications, 5 April 1941, 1.

${ }^{20}$ TNA: HS 8/321 C/8686, 5 February 1942.

${ }^{21}$ TNA: HS 8/321 Communications, 26 March 1942.

${ }^{22}$ TNA: HS 8/360 Communications, 27 March 1942.

${ }^{23}$ Foot 1993, 157.

${ }^{24}$ The Office of Strategic Services (OSS) was the United States of America's equivalent to SIS and SOE combined. This organization was to become the Central Intelligence Agency (CIA).

${ }^{25}$ Grendon Underwood had previously been STS53, and a school for training agents in the use of wireless communications.
${ }^{26}$ TNA: HS 7/34, Station Construction Section, 1. Contemporary wireless technology required transmitters and receivers to be located in separate locations to enable them to operate efficiently. If they were badly positioned, the two facilities could interfere, causing unnecessary noise within the signal.

${ }^{27}$ TNA: HS 8/321 CD/OR/1565 17/04/1942, 1.

${ }^{28}$ TNA: HS 8/321 Gambier-Parry to Ozanne, 13 April 1942, 1.

${ }^{29}$ TNA: HS 8/321 Gambier-Parry to Ozanne, 13 April 1942 , 1. The site had been vetted for interference by the General Post Office (GPO) (TNA: HS 8/321 CD/ OR/1565, 17 April 1942, 1-2).

${ }^{30}$ TNA: HS 8/321 CD/OR/1565, 17 April 1942, 1.

${ }^{31}$ TNA: HS 8/321 Gambier-Parry to Ozanne, 13 April 1942, 1-2.

${ }^{32}$ TNA: HS 7/34 Station Construction Section, 1.

${ }^{33}$ Four of these operating positions were equipped for automatic sending.

${ }^{34}$ TNA: HS 7/34 Station Construction Section, 1.

${ }^{35}$ TNA: HS 7/34 Station Construction Section, 9.

${ }^{36}$ TNA: HS 8/37 Confidential Memorandum for Colonel Donovan, 14 December 1942, 1.

${ }^{37}$ TNA: HS 7/34 Station Construction Section, 10.

${ }^{38}$ Of all of SOE's surviving wireless facilities, only access to Godington could be gained. This facility is on private land and is not accessible to the general public. ${ }^{39}$ SeeEckersley \& Ashbridge 1930, 195; Gregory \& Newsome 2010, 18; Weinberger 1924, 798. The incorporation of contemporary design standards was also observed in the construction of the new transmitter facility at Charndon. In late 1942, SOE decided to 'form a mobile construction until (known as M.C.U.77) of R.E.s [Royal Engineers] under D/PROPS Section for the purpose of carrying out work of a particularly urgent or secret nature' (TNA: HS 7/15 Properties Section History, 6).

${ }^{40}$ Originally, Room 4 and Room 5 were a single space. At a later date, a partition was inserted by a farmer to make the structure more compatible to their agricultural requirements. ${ }^{41}$ IWM HU47925.

${ }^{42}$ TNA: HS 7/34 Station Construction Section, 10, 11.

${ }^{43}$ There is no structural evidence to indicate that there was an external door. The room which held the generator originally had a full-height double door.

${ }^{44}$ This arrangement is similar to 'clean' and 'danger' areas in explosive factories (see Cocroft 2000,14).

45 'For men may come and men may go' is a quote from Tennyson's poem The Brook. The full quotation is 'I chatter, chatter, as I flow / Tojoin the brimming river, / For men may come and men may go, / But I go on for ever'.

${ }^{46}$ Further pencil graffiti is located within the doorway between the office and the transmitter room of the Transmitter Building. This comprises two pencil sketches of people of unknown origin.

${ }^{47}$ There is no documentary evidence within SOE's surviving archives, however, that there were two phases 
of construction at the organization's transmitter located at Godington.

${ }^{48}$ Despite the improvements made in SOE's wireless communications following the construction of Godington, the organization was still limited by the available technology. Owing to the dangerous nature of radio operators transmitting from within occupied Europe, it was highly desirable that SOE's agents could change frequency with great speed. This limited the ability of the German interceptors to transcribe the messages as well as pinpointing the location of the transmission. At the time, it took the $250 \mathrm{w}$ transmitters, on average, four to five minutes to accomplish this accurately. In order to overcome this issue, SOE began researching a solution. Eventually the organization developed a Wide Band Transmitting Amplifier working with a three-wire rhombic antennae. This was to provide SOE with a good signal over a wide area combined with the ability to transmit on 12 channels simultaneously. Of greater value to the organization was the ability to allow the average operator to change frequency in as little as 30 seconds (TNA: HS 7/34 Station Construction Section, 10, 11).

${ }^{49}$ Structural evidence indicates that the complex was erected in two distinct phases. It is the second phase of construction upon which the new complex at Charndon was based.

${ }^{50}$ TNA: HS 7/34 Station Construction Section, 11, 12.

${ }^{51}$ These 35 dipoles and two rhombic antennae were constructed out of $16,000 \mathrm{ft}(4,876.8 \mathrm{~m})$ of wire and five $120 \mathrm{ft}(36.58 \mathrm{~m}), 12100 \mathrm{ft}(30.48 \mathrm{~m})$, four $80 \mathrm{ft}(24.38 \mathrm{~m})$ and two $60 \mathrm{ft}(18.29 \mathrm{~m})$ masts.

${ }^{52}$ TNA: HS 7/34 Station Construction Section, 11, 12.

${ }^{53}$ TNA: HS 7/15 Properties Section History, 6.

${ }^{54}$ Eckersley \& Ashbridge 1930, 195.

${ }^{55}$ Eckersley \& Ashbridge 1930, 195.

${ }^{56}$ Gregory \& Newsome 2010, 18.

${ }^{57}$ Weinberger 1924, 798.

${ }^{58}$ This design standard was also observed in the construction of the new transmitter facility at Charndon. As this new station was based on the design of Godington, the generator was again installed in a separate building.

${ }^{59}$ Thomas \& Williamson 1941, 539.

${ }^{60}$ Eckersley \& Ashbridge 1930, 204.

${ }^{61}$ TNA: HS 7/15 Properties Section History, 6.

${ }^{62}$ Jeffrey 2010, 262, 318. Section VIII had only been established 17 months before war was declared. This section, therefore, had limited experience at the start of the conflict.

${ }^{63}$ Bletchley Park is more famously known as Station $\mathrm{X}$, home to the Government Code and Cypher School (GCCS).

${ }^{64}$ Pidgeon 2008, 27.

${ }^{65}$ Pidgeon 2008, 80, 81, 82-3, 114, 262.

${ }^{66}$ Pidgeon 2008, 80, 81, 82-3, 114, 262.

${ }^{67}$ Pidgeon 2008, 82, 287.

${ }^{68}$ IWM HU47925.
${ }^{69}$ Pidgeon 2008, 114, 285-6, 295. The US Civilian Technical Corps was a quasi-military organization established in 1941 to assist the UK in the war effort within the UK.

${ }^{70}$ Pidgeon 2008, 295.

${ }^{71}$ Pidgeon 2008, 295

${ }^{72}$ Lorain 1983, 34.

${ }^{73}$ Read \& Fisher 1984, 270.

${ }^{74}$ TNA: HS 8/358 C/6050, 21 March 1941, 2. On the formation of SOE, the organization was arranged into three branches: SO1 responsible for propaganda, SO2 for active operations and SO3 for planning and administration (Foot 1993, 23).

${ }^{75}$ TNA: HS 8/358 SO2 Communications through C, 9 March 1941, 1.

${ }^{76}$ TNA: HS 8/358 SO2 Communications, 5 April 1941, 1.

${ }^{77}$ TNA: HS 8/321 Communications, 27 March 1942.

${ }^{78}$ TNA: HS 8/360 ADP/TC/1195, 22 May 1942.

${ }^{79}$ Foot 1993, 157.

${ }^{80}$ For SOE, wireless communications enabled the organization to coordinate and communicate with members of the European Resistance. For SIS, radio contact provided the organization with a means to collect intelligence their agents had collected.

${ }^{81}$ Pidgeon 2008, 2.

${ }^{82}$ TNA: HS 7/34 Signal Planning Section, 2.

${ }^{83}$ Marks 1998, 459. The coding system used by SIS, and imposed on SOE, was the 'Poem' code. This was an insecure system which could be easily broken. It required an agent to memorize a poem and then rearrange the words and then number the letters. The numbers were then used as a key to the cipher.

${ }^{84}$ Marks 1998, 434.

${ }^{85}$ Operation NORDPOL was also known as the Englandspiel.

\section{BIBLIOGRAPHY}

Bailey, R. 2008a, Forgotten Voices of the Secret War: an Inside History of Special Operations during the Second World War, London: Ebury Press.

Bailey, R. 2008b, The Wildest Province: SOE in the Land of the Eagle, London: Jonathan Cape.

Cocroft, W. 2000, Dangerous Energy: the Archaeology of Gunpowder and Military Explosives Manufacture, Swindon: English Heritage.

Cocroft, W. 2013, 'The archaeology of military communications', Ind. Archaeol. Rev. 35:1, 65-79.

Eckersley, P. \& Ashbridge, N. 1930, 'A wireless broadcasting transmitting station for dual programme service', J. Inst. Electr. Eng. 68:405, 1149-70.

Foot, M. 1993, SOE: The Special Operations Executive 1940-46, London: Arrow Books.

Foot, M. 2005, 'Research note: the Dutch Affair', Intell. Nat. Secur. 20:2, 341-3. 
Foot, M. 2006, SOE in France: an Account of the Work of the British Special Operations Executive in France, 1940-1944, London: Frank Cass.

Giske, H. 1953, London Calling North Pole, London: William Kimber.

Gregory, D. 2013, 'SOE's Station 53B Transmitter Complex, Godington, Oxfordshire: an Architectural Survey of the Special Operations Executive's Transmitter Complex at Godington', unpubl. rep.

Gregory, D. 2015, 'Built to Resist: an Assessment of the Special Operations Executive's Infrastructure in the United Kingdom during the Second World War', University of East Anglia PhD thesis.

Gregory, D. \& Newsome, S. 2010, Cooling Radio Station: an Archaeological Investigation of a Short-Wave Receiving Station, Swindon: English Heritage.

Haestrup, J. 1976, Secret Alliance: A Study of the Danish Resistance movement 1940-45 Vol. 1, Odense: Odense University Press.

Jeffrey, K. 2010, MI6: the History of the Secret Intelligence Service 1909-1949, London: Bloomsbury.

Kedwood, H. 1994, In Search of the Maquis: Rural Resistance in Southern France 1942-1944, Oxford: Clarendon Press.

Lorain, P. 1983, Secret Warfare: the Arms and Techniques of the Resistance, London: Orbis Publishing.

Marks, L. 1998, Between Silk and Cyanide: the Story of SOE's Code War, London: Harper Collins Publishers.

Murphy, C. 2005, 'SOE's foreign currency transactions', Intell. Nat. Secur. 20:1, 191-208.

Perquin, J.-L. 2011, The Clandestine Radio Operators: SOE, BCRA, OSS, Paris: Histoire and Collections.

Pidgeon, G. 2008, The Secret Wireless War: The Story of MI6 Communications 1939-1945, Richmond: Arundel Books.

Read, A. \& Fisher, D. 1984, Colonel Z: the Secret Life of a Master of Spies, London: Hodder and Stoughton.
Seaman, M. 2005, 'A glass half full — some thoughts on the evolution of the study of the Special Operations Executive', Intell. Nat. Secur. 20:1, 27-43.

Stafford, D. 1980, Britain and European Resistance 19401945: a Survey of the Special Operations Executive with Documents, London: Macmillan.

Thomas, H. \& Williamson, R. 1941, 'A commercial 50kilowatt frequency-modulation broadcast transmitting station', Proc. IRE 29:10, 537-45.

Van der Mandele, H. 2012, 'The Dutch Affair revisited or the destructive power of organizational warfare', Intell. Nat. Secur. 28:6, 910-12.

Weinberger, J. 1924, 'Broadcast transmitting stations of the Radio Corporation of America', Proc. IRE 12:6, 745-803.

West, N. 1992, Secret War: the Story of SOE Britain's Wartime Sabotage Organisation, London: Hodder and Stoughton.

Wolters, J. 2006, 'Remarks concerning a research note on The Dutch Affair', Intell. Nat. Secur. 21:3, 459-66.

\section{ABBREVIATIONS}

BBC British Broadcasting Corporation

C Head of SIS

CIA Central Intelligence Agency

GPO General Post Office

IWM Imperial War Museum

NMR National Monument Record

OSS Office of Strategic Services

PMWR Polish Military Wireless Research

SOE Special Operations Executive

SIS Secret Intelligence Service

STS Special Training Schools

TNA The National Archives

W/T Wireless Telegraphy

\section{SUMMARY IN FRENCH, GERMAN, ITALIAN AND SPANISH}

\section{RÉSUMÉ}

Communiquer avec la Résistance Européenne : une estimation de l'équipement sans fil des Opérations Spéciales Exécutives au Royaume-Uni durant la Seconde Guerre Mondiale

Pour la première fois, une étude sur l'équipement de communication basé au Royaume-Uni des Opérations Spéciales Exécutives (SOE) est présentée. Etablie en 1940, la SOE était responsable de la coordination de tous les actes de sabotage contre l'ennemi d'outremer, actes rendus possible avec l'aide d'une liaison de communication fiable avec la résistance. A partir de l'examen des stations de la SOE du pays, cet article démontre la valeur que l'organisation a placée dans la fiabilité des communications sans fil.

\section{ZUSAMMENFASSUNG}

Verbindung mit dem europäischen Widerstand: eine Untersuchung der Radio-Möglichkeiten der Speziellen Operations-Exekutive im UK während des zweiten Weltkriegs

Dieser Artikel zeigt zum ersten Mal eine Untersuchung der Speziellen Arbeitsweise der Exekutive (SOE), der UK-basierenden Kommunikationsmöglichkeiten. 
Etabliert in 1940, war SOE verantwortlich für die Koordination aller Interventionen gegen die Sabotageakte des Feindes jenseits des Meeres. Dies war nur möglich mit der verläßlichen Hilfe eines Verbindungsringes mit dem Widerstand. Durch das Studium der heimischen SOE-Stationen will dieser Artikel den Wert der Organisation zeigen, die auf verläßlich drahtloser Kommunikation basierte.

\section{RIASSUNTO}

Comunicare con la Resistenza in Europa: una valutazione delle comunicazioni mob della 'Special Operations Executive' (SOE) nel Regno Unito durante la seconda Guerra mondiale

Questo articolo presenta per la prima volta un'analisi delle comunicazioni mobili della Special Operations Executive (SOE) operative nel Regno Unito. Fondata nel 1940, la SOE fu responsabile del coordinamento di tutti gli atti di sabotaggio ai danni del nemico oltremanica. Ciò fu possibile solo grazie all'apporto di un affidabile sistema di comunicazioni con la resistenza. Attraverso l'analisi delle Home Stations (postazioni in patria) della SOE, questo articolo vuole dimostrare l'importanza che fu attribuita a postazioni radio affidabili.

\section{RESUMEN}

Hablandocon la resistencia europea: una evaluación de las instalaciones inalámbricas del Special Operations Executive del Reino Unido durante la Segunda Guerra Mundial

En este artículo se estudia por primera vez los servicios de comunicación del Special Operations Executive (SOE) del Reino Unido. Fundado en 1940, SOE fue responsable de coordinar todos los actos de sabotaje contra el enemigo en el extranjero. Esto sólo fue posible mediante el establecimiento de una red de comunicaciones fiables con la resistencia. Estudiando los campamentos bases del SOE, este artículo demuestra el valor que dicha organización colocó en las comunicaciones inalámbricas. 